International Journal of Social Science and Economic Research

ISSN: 2455-8834

Volume:06, Issue:03 "March 2021"

\title{
SMART POWER OF INDIA'S SPACE PROGRAMME IN ASEAN REGION
}

\author{
Baruna Kumar Behera \\ Assistant Professor in Political Science, Khallikote Autonomous College, Berhampur, Ganjam, Odisha - \\ 760001, India.
}

DOI: 10.46609/IJSSER.2021.v06i03.011 URL: https://doi.org/10.46609/IJSSER.2021.v06i03.011

\begin{abstract}
"Hans J Morgenthau said international politics is a struggle for power, where each nation-state seeks to enhance its power, position and influence. In this context a question arises i.e. what should be the nature of power that is to be pursued by sovereign nation-states in this $21 \mathrm{st}$ century. Simple use of military power (hard power) may not be able to produce the preferred objectives. As per the ideas of Joseph Nye, exclusive exercise of hard power may generate revolt/resistance against the country exercising military options, which may not be endeavouring in the long run. Therefore it is advisable for each nation-state to use smart power (i.e. synthesis of hard and soft power) in their day to day affairs, which would be helpful in the fulfillment of their national interests. In this perspective, this paper seeks to understand the nature of India's space programme and its possible applications in the ASEAN region. Growing super power rivalry between USA \& China and occurrence of natural disasters in the Southeast Asia region make a perfect case for India to pursue smart power policies in this region to serve its national interests"
\end{abstract}

Key Words: India, Space Programme, ASEAN, Smart Power.

\section{Introduction}

Middle of the twentieth century witnessed emergence of space era, when earth's first artificial satellite Sputnik - I was placed in the low earth orbit by the erstwhile Soviet Union. National prestige was the main motivating factor behind the embracement of space technology promotion activities during the initial period of space era. Cold war power politics and military arms race between USA and USSR were instrumental for the evolution of space age. Space technology is a double edged sword that can be harnessed for peaceful as well as for military purposes. Later on a number of peaceful applications of space technology were identified. This development encouraged many countries including third world countries to dream of having their own space programmes, an instrument that could act as a means for their socio - economic upliftment and 


\section{International Journal of Social Science and Economic Research}

ISSN: $2455-8834$

Volume:06, Issue:03 "March 2021"

empowerment. India remained not aloof from this world wide technological pursuance. In 1969, India formally and officially launched its dedicated space institution i.e. Indian Space Research Organisation (ISRO).

\section{India's space initiative: A chronological outline}

At present India is regarded as one of the important space faring countries of the world. India's status has altered from a post-colonial state to an emerging power in this twenty-first century. This makeover has not been achieved in a short period of time, but it is the outcome of perseverance with which India has been working in the last seven decades(Behera 2020). Once upon a time, bullock cart constituted principal mode of transportation in India, now the same India has become one of the leading players of space technology in this world.

India concentrated all its energies on nation-building - economic and industrial growth - after gaining independence in 1947. India's first Prime Minister, Pandit Jawaharlal Nehru, was well aware that science and technology could pave the way for India's development. According to him, it is only science that can solve the hunger and poverty problems (Goodreads.com 2020). In his outlook Nehru was very scientific and rational. He knew that scientific and technological self-reliance was crucial for India's socio-economic growth.

Nehru's view about the role of science in national reconstruction could be very well realized in the Resolution on Scientific Policy, adopted by the Indian Parliament on $04^{\text {th }}$ March 1958. It stated that "It is an inherent obligation of a great country like India with its traditions of scholarship and original thinking and its great cultural heritage, to participate fully in the march of science, which is probably mankind's greatest enterprise today"(Anusandhan.net/ 2020). Nehru always supported any endeavor for the development of science and technology in India.

No other developing country had put so much emphasis on science and technology as India had done on its modernization and economic growth. Even before India achieved independence, its leaders strongly believed that science and technology could solve the country's myriad problems(Baskaran 2005).

Based on this passion, India created a number of scientific institutions. "These included the Tata Institute of Fundamental Research (TIFR), the Council of Scientific and Industrial Research (CSIR), the Atomic Energy Commission (AEC), the Indian Council of Agricultural Research (ICAR) and the Physical Research Laboratory (PRL)"(Baskaran 2005).

Dr. Vikram Sarabhai and Dr. Homi Bhabha were the pioneers of high-end technology in independent India, particularly in the field of space technology and atomic energy respectively. They were determined to use high-tech technologies to solve the real problems of man and 


\section{International Journal of Social Science and Economic Research}

ISSN: $2455-8834$

Volume:06, Issue:03 "March 2021"

society. This resolve can be very well appreciated from the following statement of Dr. Vikram Sarabhai which he made in 1968 at Thumba: "There are some who question the relevance of space activities in a developing nation, to us there is no ambiguity of purpose. We do not have the fantasy of competing with the economically advanced nations in the exploration of the moon or the planets or manned space flight. But we are convinced that if we are to play a meaningful role nationally and in the community of nations, we must be second to none in the applications of advanced technologies to the real problems of man and society, which we find in our country”(ISRO, 2020).

The process of space exploration and technology accumulation in India can be traced back to the year 1960s. The whole space exploration process in India can be divided into four stages namely science, learning, threshold and commercial. Each stage has specific thrust and activities. A variety of factors such as national prestige, self-reliance agenda, foreign exchange crisis, import substitutions, geopolitical considerations and export controls had affected India's space programme in varying degrees(Baskaran 2005).

In an institutional manner, the space programme commenced in 1962 with the formation of the Indian National Committee for Space Research (INCOSPAR) under the administrative control of Department of Atomic Energy. In opposition to the global tendency in space technology, which was concerned with the military use of space technology, India commenced its space programme with the aim of peaceful use of space technology.

In 1962, INCOSPAR decided to establish Thumba Equatorial Rocket Launching Station (TERLS) in Kerala so that a major thrust could be given to the indigenous space technology endeavour. At the beginning American sounding rockets like Nike- Apachie, French sounding rockets like the Centaure, British and Russian rockets were launched from Thumba rocket launching station. The launch of such sounding rockets gave fundamental and realistic understanding of rocket operations to the Indian scientists(Behera 2020).

Recognizing the necessity of indigenous technology and the massive socioeconomic spinoffs of space technology, in 1969 INCOSPAR was transformed into ISRO (Indian Space Research Organisation). ISRO's institutional configuration was further improved with the formation of Space Commission and Department of Space in 1972 (Bhatia 1985).

Space programme in India is dedicated to two types of activities: (1) It manufactures satellites for remote sensing and communication purposes and (2) It also manufactures satellite launch vehicles to put these satellites in higher orbit (Mistry 2001).

After becoming a full-fledged governmental agency in 1969, ISRO started its journey in a more optimistic and productive manner with allocated budget, time-bound targets. ISRO started work 


\section{International Journal of Social Science and Economic Research}

ISSN: $2455-8834$

Volume:06, Issue:03 "March 2021"

on indigenous satellite and satellite launch vehicle programmes during the 1970s-1980s. In 1975, India sent its first Arybhatta satellite, using a Russian launch vehicle. After that ISRO turned its attention on indigenous satellite launch vehicle production. By 1979, it was ready to launch the Satellite Launch Vehicle, SLV-3. However the test was not successful because of some problems in the second stage of SLV-3. ISRO successfully launched its SLV-3 on 19 July 1980 and became the world's sixth nation to orbit a satellite by an indigenously developed satellite launch vehicle after the USSR, the USA, France, Japan and China (ISRO, 2020).

The project work of ASLV (Augmented Satellite Launch Vehicle) and PSLV (Polar Satellite Launch Vehicle) was undertaken by ISRO during the 1980s-1990s. ISRO was not able to carry out all the projects concurrently due to economic constraints. However, in order to test different technologies and hardware to be used in PSLV and its successor GSLV, it was agreed to perform a limited ASLV test. ISRO performed four ASLV experimental flight tests between 1987 and 1994(Baskaran 2005). Out of this, first two tests were failure while success was registered in the last two tests.

During this time Wernher Von Braun, the father of modern military missile, visited ISRO and observed "if you have to do anything in rocketry do it yourself, SLV-3 is a genuine Indian design and you may be having your own troubles. But you should always remember that we do not just build on success, we also build on failure"(Abdul Kalam, A. P. J. 1999).

ISRO had begun operating PSLV in the 1990s. PSLV is a four stage satellite launch vehicle. Alternatively it uses solid and liquid propellant. The first PSLV test was performed in September 1993. It was nevertheless not a success. The first successful launch was made in 1994 and since then the PSLV has been India's work horse for satellite launch. It is capable of placing both remote sensing and communication satellites in the polar orbit (Behera 2020).

Following PSLV's successful project, ISRO agreed to work on GSLV, PSLV's next-generation launch vehicle. ISRO wanted the cryogenic rocket engine for the GSLV class launch vehicle which would be used as a third stage in the GSLV. ISRO moved to Russian space organisation, Glavkosmos, for this purpose. Glavkosmos was prepared to provide the technical know-how of cryogenic engine to ISRO. But in May 1992, the USA rejected the agreement under the MTCR (Missile Technology Control Regime) provisions and placed sanctions on ISRO. The Russians were allowed to sell the cryogenic engines after considerable negotiations but not to transfer the technology to India. The technology journey for GSLV class rockets was full of challenges for ISRO; however, ISRO was successful at the beginning of this millennium in the operationalization of the GSLV class satellite launch vehicle. ISRO is now competent to manufacture advanced version of GSLV i.e. GSLV Mark III launch vehicle, capable of carrying heavier satellites with more technical spin offs(Behera 2020). 
International Journal of Social Science and Economic Research

ISSN: 2455-8834

Volume:06, Issue:03 "March 2021"

\section{Strategic utility of India's space programme: Development and Defence}

\section{Development aspect:}

Space technology can be used for the purposes of defence and development. Space technology is no longer a means of achieving political hegemony, but becomes an economic commodity and a tremendously valuable source of know-how. It also becomes an ideal instrument of soft power projection.

Thousands of spin-off products have been identified from space technology applications in fields like human resource development, environmental monitoring, natural resource management, public health, medicine, public safety, telecommunications, computers, information technology, industrial productivity,

manufacturing technology and transportation (Behera 2020).

Space technology provides a major return on national space research investments. Satellites are the perfect ways to realize the dividend of space technology. ISRO mainly builds two types of satellite: (1) Communication satellites and (2) Remote sensing satellites.

ISRO enjoys self sufficiency in the satellite system. Indian communications and remote sensing satellites are seen as one of the world's largest satellite networks. Via telemedicine, teleeducation, e-governance, meteorology, networking, broadcasting, resource management and disaster management, the benefits of these satellites making inroads in the life of common man.

\section{Indian communication satellites}

The INSAT and GSAT satellites have played an important role in the growth of India's communication infrastructure. Television network now covers over 90 percent of India's population. Telephone services now connect rural areas. Communication satellites are now being used by a range of industries, such as banks, financial services, capital markets, the manufacturing industry, the fast-moving consumer goods business and medium and high-tech firms in their efforts towards development and expansion. Communication satellites also play a significant part in the upliftment of rural areas. Now the INSAT and GSAT series satellites are providing educational programmes across the country. Communication satellites are capable of giving the common people of India immediate socio-economic benefits of space technology. In the following areas communication satellites are being used now(Behera 2020):

$>$ TV broadcasting;

$>$ Business communications;

$>$ Mobile satellite services; 
International Journal of Social Science and Economic Research

ISSN: 2455-8834

Volume:06, Issue:03 "March 2021"

$>$ Radio monitoring;

$>$ Search and rescue services;

$>$ VSAT connectivity;

$>$ Data collection platforms;

$>$ Meteorology;

$>$ Disaster warning system;

$>$ Telemedicine; and

$>$ Training and education

\section{Indian remote sensing satellites}

The IRS (Indian Remote Sensing) satellite programme is now standing out as a society-oriented, people-oriented and development-oriented programme. As ISRO's capability increased, Indian remote sensing satellite programme has become increasingly important. The IRS satellites are now able to identify various observational needs for the development of different sectors of the economy. Indian remote sensing satellite programme has achieved remarkable success in both its power and performance in a short span of time. A range of spatial resolution capability from 1 $\mathrm{km}$ to $1 \mathrm{~m}$ has been achieved from Bhaskara-1, the first experimental earth observation satellite to Cartosat-2. Now ISRO launches Cartosat-3 with a resolution potential of $20 \mathrm{~cm}$ (Behera 2020).

The Indian system for remote sensing was commissioned with the launch of IRS-1A in 1988. The programme of indigenous remote sensing satellites has made India self-confident in its earth observation activity. This also eliminated India's reliance on satellite images collected from satellites like Landsat and SPOT. ISRO has launched many operational remote sensing satellites, starting with IRS-1A in 1988 (Behera 2020).

India today operates one of the largest constellations of remote sensing satellites. "Currently, *thirteen* operational satellites are in Sun-synchronous orbit - RESOURCESAT-1, 2, 2A CARTOSAT-1, 2, 2A, 2B, RISAT-1 and 2, OCEANSAT-2, Megha-Tropiques, SARAL and SCATSAT-1, and *four* in Geostationary orbit - INSAT-3D, Kalpana, INSAT 3A and INSAT 3DR"(ISRO, 2020). The data from these satellites are used for many applications that include irrigation, water supplies, urban planning, rural development, mineral prospecting, climate monitoring, forestry, ocean resources and disaster management (ISRO, 2020). Remote sensing satellites play a major role in the areas below:

$>$ Earth observing satellites can be used for sustainable development and to reduce deprivation. 


\section{International Journal of Social Science and Economic Research}

ISSN: $2455-8834$

Volume:06, Issue:03 "March 2021"

Agricultural sector can be transformed into a profitable business by using remote sensing satellites.

$>$ Remote sensing satellite will boost the quality of life.

$>$ Remote sensing satellites can be employed for urban planning and for infrastructure development.

$>$ It can support India in its river-linking projects which are most ambitious.

$>$ In the administration of forest and biodiversity, remote sensing satellites can assume a very important responsibility.

By utilizing remote sensing satellites, India can maintain a watch over its territories.

\section{Defence aspect}

In the twentieth and twenty-first centuries, space technology had dramatically changed military warfare. Now, importance is attached to the satellite network, which is becoming increasingly useful for military planning and becoming instrumental in increasing the effectiveness of the armed forces. Satellites are now used as 'real multipliers of power.'(Stares 1987) Satellites for detection and surveillance are used to locate, track and target opposing military forces. Communication satellites are able to disseminate information within a vast area very quickly. This is instrumental in enhancing the armed forces' efficiency in war. The increasing use of space systems has profoundly altered the conduct of military operations (Stares 1987). A nation without such technical facilities cannot expect success from those equipped with such modern help. The peace time applications of military satellites can be divided into five principal missions.

$>$ Intelligence Gathering

$>$ Arms Control Monitoring

$>$ War Planning

$>$ Crisis Management

$>$ Early Warning of Attack

With its present strength and capabilities, India's space programme is able to perform all of the above-mentioned functions. In this regard, the following examples adequately demonstrate the potential of the Indian space-based assets: the surgical strike of the Indian armed force which was carried out in 2016 in response to the Uri terror attack and the assault of the Indian air force on the terror camps located at Balakot in Pakistan in February 2019 demonstrated the capacity and usefulness of India's space-based assets. Without the assistance of space-based satellites these preventive response and precise preparation are almost impossible. Military preparedness is absolutely necessary for peacekeeping and satellites have become inevitable in this context. On 


\section{International Journal of Social Science and Economic Research}

ISSN: $2455-8834$

Volume:06, Issue:03 "March 2021"

March 27, 2019, the successful anti-satellite missile test (Mission Shakti) truly demonstrated the hard-power dimensions of India's space programme (Behera 2020).

ISRO's remote sensing satellites are capable of meeting the military needs of India, particularly in the field of surveillance and reconnaissance. The satellites of the CARTOSAT and RISAT series have already proven their usefulness in the military domain. ISRO plans to launch a range of sophisticated military satellites to improve the security forces' surveillance capabilities. Cartosat - 3, which was recently launched by ISRO in 2019, is stated to be able to zoom in to a resolution of $0.2 \mathrm{~m}(20 \mathrm{~cm})$, which is considered the best in the world (The Times of India 2019). Clean pictures of small items such as a pistol or an enemy bunker would be captured by it. Reports also say images from old satellites of the RISAT series were used to plan the surgical strike which was carried out in 2016 in response to the Uri terror attack. It is also said that the recent 2019 Balakot air strike conducted in Pakistan by the Indian Air Force also took technical support from the space-based assets held by ISRO (The Times of India 2019).

In addition, ISRO is considering launching two new remote sensing satellites, Geo Imaging Satellites (Gisat - I and II). Satellites from the Gisat series will have military as well as civilian applications.(The Times of India 2019)

India successfully tested the first anti-satellite missile (Mission Shakti) on March 27, 2019, thus heralding the emergence as a major force in space. With this missile test, India entered as the fourth member of an exclusive community of countries after the US, Russia and China. In this era of artificial intelligence and information technology, satellites can be equated with eyes that view everything from space. Missiles, anti-missile defence systems, navigation networks, etc. make use of satellites for their operations either directly or indirectly (Behera 2020).

Thus, a nation that has the capacity to disable these satellites from its ground-based facilities would play a significant role in the coming modern warfare. This anti-satellite missile test enhanced India's hard-power projection with large geopolitical ramifications. The Government of India recently cleared up the establishment of the Defense Space Research Agency, which will be responsible for developing space warfare systems and technologies. The current government's decision in this regard shows India's tendency to project the hard-power aspect of its space programme (Behera 2020).

It should be noted however; that India is opposed to the armament of outer space and is of the opinion that outer space should not become a conflict region. India stands for collective efforts to enhance space-based asset's safety and security. India is a signatory to the Outer Space Treaty of 1967 and India ratified it in 1982. 
International Journal of Social Science and Economic Research

ISSN: 2455-8834

Volume:06, Issue:03 "March 2021"

\section{Soft power applications of India's space programme}

Before going to discuss relevance of India's space programme in the dome of soft power, it will be necessary to know what soft power means in international politics. The ability to manipulate one without using coercive tactics is soft power. Persuasion is the secret to soft power use. Culture, democratic ideals and foreign policies are cited in international relations as the principal instruments of soft power(Behera 2019).

Joseph Nye invents the term 'soft power' in a 1990 Book, "Bound to lead: The changing nature of American Power". In his 2004 book, "Soft Power: The Means of Success in World Politics," he further established this idea.(Wikipedia, 2020)

Soft power is just as critical as the control of hard order. When a State can make its power seem valid in other people's eyes, it can face less opposition to its wishes. If the culture and philosophy are enticing, then others would follow more readily. Co-optive power is a country's ability to arrange situation in such a way that other countries establish priorities or identify their interests in a manner compatible with it (Jr. 1990).

The influence of enticing ideas or the ability to set the political agenda in a way that forms the desires of others has long been understood by the political leaders and philosophers. Intangible power tools such as culture, ideology and institutions tend to equate the potential to influence what other countries want (Jr. 1990).

With the aid of knowledge extracted from space-based technologies, issues such as climate change, implementation of sustainable development goals, flood control, resource management, crop planning, meteorology, urban planning, weather forecasting, etc. can be tackled very well. This application of space technology is a kind of projection of soft power. A country with a comprehensive space programme can manage the aforementioned problems easily and ISRO is a world-renowned leader in this respect (Behera 2019).

ISRO has been supporting the aforementioned points via its remote sensing and communication satellites and will continue this approach. ISRO should try to provide the developing countries with space-based knowledge, as China has done. India has been seen as a leading Third World country and India's efforts to provide space-based information to third world countries will be a win-win strategy for the national interests of India (Behera 2019).

The best examples of India's space programme's soft power dimensions are the launch of South Asia satellite (also known as the SAARC satellite) and IRNSS (Indian Regional Navigation Satellite System) (Rao 2014). SAARC satellite is designed to provide six SAARC countries with spatial benefits, namely Afghanistan, Bangladesh, Bhutan, Maldives, Sri Lanka and Nepal. This 


\section{International Journal of Social Science and Economic Research}

ISSN: $2455-8834$

Volume:06, Issue:03 "March 2021"

is an effort to forge a confidence and goodwill among India's small South Asian neighbours (Behera 2019).

Similarly, IRNSS is planned to provide navigational services across 1500 kilometers outside the geographical limits of India. Civil aviation, marine navigation, road transport and disaster management are some of the areas which benefit from IRNSS operationalization. India's expertise in using its space programme to accelerate socio-economic development is of immense importance, especially for countries in the third world, which from the technical point of view have been described as have-nots (Behera 2019).

All these aforementioned points argue that India should use its space programme as a tool of soft power projection. This approach will not only help India internally but also enable India to achieve its national interests abroad in a smooth way.

\section{Hard power applications of India's space programme:}

Hard power applies to using military \& economic means to control other people's behaviours. By fact this type of power is violent in nature. In comparison to soft power, its nature is opposite. According to Joseph Nye, hard power requires the opportunity to use the carrot and the stick of economic and military strength to make others obey your will (Behera 2019). It is obvious from the above that hard power refers to a country's military ability.

Space technology can be used for collecting intelligence, tracking arms control measures and designing various weapon systems. These space-based technologies can improve a country's military capabilities significantly(Behera 2019). With its present power, India's space programme is able to perform all of the above-mentioned functions. The successful anti-satellite missile test (Mission Shakti) on March 27, 2019 demonstrated truly the dimensions of hard power of space programme of India (Aneja 2019). Many academics argue that India's space programme was instrumental in establishing its missile agenda.

\section{Prospects for smart power application: The case of space programme}

Smart power means a synthesis of hard power and soft power. In foreign relations, using hard force, i.e. military approach, isn't always advisable. Soft power is perceived to have a lasting impact as being more successful. Culture, political values and foreign policy are cited as the main instruments of soft power in international politics. Coercion is not sufficient for persuasion, but persuasion with nonviolent methods can have a profound impact on bilateral and multilateral relations. The problem of resistance is likely to be rare when applying smart power and the probability of acceptance is greater As described above, India's space programme is capable of harnessing space technology's constructive and destructive potential. On the one hand, it can 


\section{International Journal of Social Science and Economic Research}

ISSN: $2455-8834$

Volume:06, Issue:03 "March 2021"

manufacture remote sensing and communication satellites designed to lift its people's living standards and on the other, it can create advanced weapons and various surveillance satellites to exploit the military aspects of the space programme (Behera 2019).

\section{The case of Indian space programme in ASEAN region:}

From the aforementioned points it is clear that space programme of India is a worth element of smart power capable of demonstrating both hard and soft power. Particularly soft power dimensions of space programme such as monitoring of natural phenomenon, management of natural disaster, crop estimate, tele-education, tele-medicine etc. are the important areas, where India can provide assistance to the needy countries.

India's successful launch of the South Asia Satellite (SAS) in 2017 to boost communication and enhance disaster management among its six neighbours, namely Afghanistan, Bangladesh, Bhutan, Maldives, Sri Lanka and Nepal, has opened up new horizons of engagement in the region and helped India to create a unique position for itself in space diplomacy (Venkatasubramanian 2017).

The 2.230-kg communication satellite (GSAT-9), with a 12-year mission life, will support effective communication, broadcasting and internet services in the region of South Asia, which is geographically challenging and economically lagging behind with limited technological resources. ISRO had designed \& launched the satellite and the project cost India around Rs. 450 crore (Venkatasubramanian 2017).

South Asia satellite is a perfect case of smart power of space programme of India. On the same line a project of Southeast Asia satellite or ASEAN satellite may be contemplated by the policy makers of India to further cement India's relations with ASEAN region.

Southeast Asia which hosts 10 member countries of ASEAN namely Vietnam, Indonesia, Singapore, Malaysia, Myanmar, Brunei, Philippines, Thailand, Laos and Cambodia, is an important area for the foreign policy calculation of India. None of the countries of ASEAN bloc has well developed space programme like that of India. All the ASEAN countries are developing countries having their own developmental and defence needs. On the line of SAARC satellite, India can contemplate to launch a satellite fully dedicated to serve developmental and defence needs of ASEAN countries. Such gesture of India will definitely have a positive impact on the overall India-ASEAN relations.

According to Government Space Programmes 2019 report, prepared by Euroconsult, global government space budgets totaled $\$ 70.9$ billion in 2018. This report was published in July 2019 (Seminari 2019). According to this report, following are the top spenders of ASEAN region in 
International Journal of Social Science and Economic Research

ISSN: 2455-8834

Volume:06, Issue:03 "March 2021"

space programmes: Indonesia (USD 205 Million), Vietnam (USD 45 Million), Thailand (USD 30 Million), Singapore (USD 29 Million), Laos (USD 17 Million), and Malaysia (USD 10 Million) (Euroconsult 2019). According to this Euroconsult report, India spends around USD 1493 Million on its space programme in 2018.

International cooperation is a strategic area for a space programme. Political, economic, cultural, human personalities as well as scientific and technological factors influence relations with other countries. India has always acknowledged the aspect of space beyond national concerns, which can only be addressed along with international partners. With ISRO maturing in experience and technical capabilities over the years, the potential for cooperation has become multifaceted (ISRO, 2020).

After its inception, foreign collaboration has been part of Indian space programme. "Establishment of Thumba Equatorial Rocket Launching Station (TERLS), conduct of Satellite Instructional Television Experiment (SITE) and Satellite Telecommunication Experiment Project (STEP), launches of Aryabhata, Bhaskara, Ariane Passenger Payload Experiment (APPLE), IRSIA, IRS-IB satellites, INSAT series of satellites, Mission to Moon, etc., have the components of international cooperation" (ISRO, 2020).

Out of 10 ASEAN countries, India has secured bilateral space cooperation with 06 Southeast Asian countries namely Vietnam, Indonesia, Brunei, Singapore, Thailand and Myanmar.

As announced by India's Prime Minister at the India-ASEAN Summit in October 2010, ISRO is pursuing a proposal to help ASEAN countries to obtain and process data from Indian Remote Sensing Satellites (RESOURCESAT-2 and OCEANSAT-2), as well as to provide training in space technology and applications (Press Information Bureau, India, 2018).

India is pursuing international cooperation with space agencies of around 43 nations and 5 multilateral bodies for the peaceful use of outer space (Press Information Bureau and India 2018). Formal cooperative arrangements either in the form of Agreements or Memoranda of Understanding (MoU) or Framework Agreements do also exist with following ASEAN countries namely Brunei, Indonesia, Myanmar, Singapore, Thailand and Vietnam (ISRO, 2020). Under this background, it is important to map space programmes of various ASEAN countries and their technological collaboration with India.

Mapping space programmes in ASEAN region

Vietnam 


\section{International Journal of Social Science and Economic Research}

ISSN: $2455-8834$

Volume:06, Issue:03 "March 2021"

The Space Technology Institute (STI) and the Vietnam National Space Center (VNSC) are the leading government agencies in Vietnam responsible for the country's space programme, under the Vietnam Academy of Science and Technology (VAST). The STI conducts space science and technology research, and VNSC is responsible for developing projects. VNSC is also responsible for implementing projects of international cooperation and for monitoring, maintaining and managing the earth observation satellites in Vietnam. In 2017, VNSC announced the country will produce its own satellite by 2022 and become one of the region's leading countries in this sector (Sarma 2019).

In 2016, India and Vietnam signed the Inter-Governmental Framework Agreement for peaceful exploration of outer space. India has set up a satellite tracking and imaging center in Ho Chi Minh city that gives Vietnam access to images of India's earth observation satellites covering the region, including China and the South China Sea. India and Vietnam signed a MoU in 2018 to strengthen cooperation in the information and broadcasting, as well as in space cooperation. Both the countries also agreed on the arrangement for the establishment of a tracking and data reception station and data processing facility (Sarma 2019).

\section{Indonesia}

The Indonesia government established the national space agency called LAPAN in 1962. Indonesia is one of the first countries that already have an existing National Space Law — the 2013 Indonesian Space Act that puts emphasis on space science, remote sensing, aerospace technology development and the launch and marketing of space activities. In addition to helping to launch the experimental LAPAN-Tubsat microsatellite in 2007, Indonesia has also signed a cooperative agreement with India's ISRO to host a ground station for Indian satellite telemetry and monitoring purposes (Sarma 2019).

\section{Malaysia}

Malaysia has been utilizing foreign remote-sensing data since the 1970s and established a remote sensing station in 1988. Country's space programme was progressively growing under the guidance of its space organization, ANGKASA. ANGKASA was established in the year 2002 under the control of Ministry of Science, Technology and Innovation (MOSTI). Its space policy is motivated by the need for self-reliance in national security. Malaysia developed its indigenous space technology in collaboration with foreign partners like Britain and South Korea. The National Space Policy was approved by the Malaysian government in 2010. On 20th February 2019, the Malaysian Cabinet approved the formation of the Malaysian Space Agency (MYSA) through the merger of the Malaysian Remote Sensing Agency (MRSA) and the National Space Agency (ANGKASA) (Malaysian Space Agency (MYSA) 2019). "The objective of MYSA is to 
International Journal of Social Science and Economic Research

ISSN: 2455-8834

Volume:06, Issue:03 "March 2021"

ensure the development and management of the national space sector in a strategic, organized and comprehensive manner" (Malaysian Space Agency (MYSA) 2019).

\section{Thailand}

Thailand has been using its space based information for the control of its natural resources, improvement of science and technology and for formulating national and domestic security plans. Thailand developed its space programme with the assistance of established space powers such as the United States, China and Japan. It is one of the founding members of the Asia-Pacific Space Cooperation Organization (APSCO) which is run by China. It also signed an MOU for cooperation in the Small Multi-Mission Satellite (SMMS) project. China, Iran, Republic of Korea, Mongolia and Pakistan are other members of this project (Sarma 2019).

The Thai space organization namely Geo-Informatics and Space Technology Development Agency (GISTDA) was founded in 2000 with the objective of development of satellite technology and remote sensing (Sarma 2019).

\section{Singapore}

Singapore mainly puts emphasis on the peaceful use of space technology such as communication, resource management and educational empowerment. Singapore launched its first satellite named X-sat in 2011. Singapore Defence Science Organization and Nanyang Technological University (NTU) were responsible for the manufacture of this satellite. With the aid of India's Polar Satellite Launch Vehicle (PSLV-C16) the $105 \mathrm{~kg}$ micro-satellite was successfully launched at a cost of US\$ 29 million in 2011. Its aim is to track soil erosion around Singapore and to observe environmental changes (Sarma 2019). In January 2019, scientists at Nanyang Technological University successfully launched and deployed their 9th satellite. The AOBA VELOX-IV nano-satellite was launched by the Japan Aerospace Exploration Agency (JAXA)'s Epsilon-4 rocket under the Innovative Satellite Technology Demonstration Programme (NANYANG TECHNOLOGICAL UNIVERSITY 2019).

\section{Philippines}

Philippines comprise more than 7,000 islands. Its location within the Pacific Ring of Fire makes it vulnerable to natural disasters like earthquakes and tsunamis. It is also rich in biodiversity. Philippines very well understand the advantages of developing space technology. Its space activities began with the purchase of Agila-2, a telecommunication satellite intended to provide coverage in the Asia Pacific region, in the 1990s (Sarma 2019). 
International Journal of Social Science and Economic Research

ISSN: 2455-8834

Volume:06, Issue:03 "March 2021"

Philippine Space Agency or PhilSA, is Philippine's national space agency. The Philippine Space Act created this agency and this act was signed into law on 8th August 2019. It is planned to oversee and run the space programme of the Philippine Government, which has been decentralized and managed by various agencies of Department of Science and Technology (DOST) (Silver 2019).

PhilSA's aims include national security, hazard management and mitigation of climate change as well as research and development in technologies such as satellites, increasing private player participation in space industry and international collaborations (Silver 2019).

\section{Laos}

Laos lacks an agency dedicated to space technology development. It does not have the infrastructure required for the pursuance of space programme (Sarma 2019). In 2015, China designed and launched a communication satellite for Laos, as provided for in a bilateral agreement (Clark 2015). In 2015, a Chinese Long March Rocket placed LaoSat-1 in geostationary orbit. Laos is looking at other countries to further grow its satellite programme. Laos is one of the poorest countries of Southeast Asia, despite this Laos spent around USD 17 Million in its space activities in 2018, which was fifth highest in ASEAN region during 2018 (Euroconsult 2019).

\section{Myanmar}

Since the 1990s remote sensing has been in use in Myanmar. In 1997 the implementation of space studies began in the country with the up gradation of the Department of Aerospace Engineering (Sarma 2019). With the assistance of Hokkaido University of Japan, Myanmar is mulling establishing its own national space agency and obtaining a small satellite for Earth observation (Spacewatch, 2018).

The first Myanmar-India Friendship Center for Remote Sensing and Data Processing (MIFCRSDP) was set up in 2001 as a bilateral initiative between the Ministry of Science and Technology (MOST), Myanmar and the ISRO of India (Sarma 2019).

\section{Cambodia}

Cambodia has been slow in developing its technology in space domain. It was only in 2018 that the country signed a framework agreement with China Great Wall Industry Corporation (CGWIC), which is the international commercial arm of China's space agency, for a new communication satellite, Techo1; it will be their first communication satellite, and will be used 


\section{International Journal of Social Science and Economic Research}

ISSN: $2455-8834$

Volume:06, Issue:03 "March 2021"

for telecommunications, disaster relief, national security and government services. The satellite is expected to launch in 2021 and will have a life span of 15 years (Goh 2018).

\section{Brunei}

Brunei doesn't have a dedicated government institution to pursue space programme. Currently Brunei Meteorological Service (BMS), Civil Aviation Department (DCA), and Communications Ministry play important roles in providing space-based applications to the Brunei people (Sarma 2019).

In 2018, a MoU was signed between Brunei and India for space cooperation and for the establishment of a telemetry, tracking and command station (TT\&C) in Brunei for orbiting satellites and launch vehicles (Spacewatch 2018b).

\section{Conclusion}

India with its existing space infrastructure is able to demonstrate both hard and soft power and truly India's space programme is an instrument of smart power capable of serving national interests of India. ISRO's remote sensing and communication satellite systems are competent to serve defence and development needs of India. India with its enhanced space capabilities is able to extend these space based benefits to other countries. South Asia satellite also known as SAARC satellite is a perfect example of strategic use of India's space programme. Such initiative improves image of India among its neighbours. On this line, the idea of an ASEAN satellite may be contemplated by India to extend space based technologies to Southeast Asian countries.

All the member countries of ASEAN are keen to invest in space technology, which not only ensure their developmental needs but also capable of securing their security interests too. Given the rise and assertiveness of China, the region of Southeast Asia is going to witness much upheaval in coming future. Dispute over South China Sea, rising brazenness of China and desire of USA to maintain the status quo are going to characterize Southeast Asia in coming time. Under such conflicting scenario, space based services may be very useful for ASEAN countries. India with its space competence is capable to provide such services to ASEAN countries.

None of the countries of Southeast Asia is a major space faring entity in present time. For their development in space technology, Southeast Asian countries initially had taken assistances from developed space powers of West. Now there is a shift in this regard, emerging space powers of Asia namely China, Japan and India are seen as major competitors in this domain. Among these three new players, China and Japan have already established two regional institutions to further their space cooperation with the countries of Southeast Asia. Names of these two organizations 


\section{International Journal of Social Science and Economic Research}

ISSN: $2455-8834$

Volume:06, Issue:03 "March 2021"

are Asia-Pacific Regional Space Agency Forum (APRSAF) led by Japan and Asia-Pacific Space Cooperation Organization (APSCO) spearheaded by China. India does not have any institutional arrangements in ASEAN region to boost its space cooperation with the countries of this region, although some bilateral agreements to strengthen space cooperation with the countries of ASEAN have been made.

ASEAN countries are very important for India. In 2018, it is estimated that ASEAN region had a combined GDP of \$ 2.7 trillion. At present, India's GDP is nearing \$ 3 trillion and India is dreaming to become a $\$ 5$ trillion economy in near future. To realize this objective, it is important for India to have robust relationships with the ASEAN countries. Given the geographical location of ASEAN countries, historical and cultural linkages, it is prudent for India to have good relations with the countries of this region. In this context, the use of space programme as an instrument of smart power would be immense helpful in achieving national interests of India. National interests are primary interests for every Nation-State, however it should be achieved in a smart way, where the degree of coercion would be minimum and passion for persuasion would be maximum.

\section{References}

Abdul Kalam, A. P. J., and Arun Tiwari. 1999. Wings of Fire: An Autobiography. Hyderabad, Andhra Pradesh: Universities Press. http://ycis.ac.in/CEGC Library/English/wings of fire.pdf.

Aneja, Atul. 2019. "Anti-Satellite Test Can Steel India's Ballistic Missile Defences : Chinese Blog." The Hindu. https://www.thehindu.com/news/international/anti-satellite-test-can-steelindias-ballistic-missiledefences-chinese-blog/article26803333.ece.

Anusandhan.net/. 2020. "Scientific Policy Resolution 1958." Anusandhan.net. http://anusandhan.net/snt_system/main_template.jsp?file=snt_policy_resolution.jsp.

Baskaran, Angathevar. 2005. "From Science to Commerce: The Evolution of Space Development Policy and Technology Accumulation in India." Technology in Society 27 (2): 155-79. doi:10.1016/j.techsoc.2005.01.003.

Behera, Baruna Kumar. 2019. "India's Space Programme in 21st Century." Third Concept 33 (August): 15-18. https://www.thirdconceptjournal.co.in/pdf/August-_2019_PDF.pdf.

Behera, Baruna Kumar. 2020. "India' s Initiative in Defense and Development: The Case of Space Program India.” IUP Journal of International Relations XIV (1).

Bhatia, Anita. 1985. "INDiA ' S SPACE PROGRAM Cause for Concern ?” Asian Survey 25 (10): 1013-30. http://www.jstor.org/stable/2644178. 
International Journal of Social Science and Economic Research

ISSN: 2455-8834

Volume:06, Issue:03 "March 2021"

Clark, Stephen. 2015. "China Launches First Satellite for Laos." Spaceflightnow. https://spaceflightnow.com/2015/11/22/china-launches-first-satellite-for-laos/.

Euroconsult. 2019. "Government Space Programmes Benchmarks, Profiles and Forecast to 2028." Euroconsult.

Goh, Deyana. 2018. "China to Build and Launch Cambodia's First Satellite." Spacetechasia. https://www.spacetechasia.com/china-to-build-and-launch-cambodias-first-satellite/.

Goodreads.com. 2020. “Quote by Jawaharlal Nehru.” https://www.goodreads.com/quotes/90239it-is-science-alone-that-can-solve-the-problems-of.

Herres, Robert T. 1986. "The Military's Use of Space Based Systems.” SIGNAL 40 (3): 41-48. doi:10.1017/CBO9781107415324.004.

ISRO. 2020a. "Dr. Vikram Ambalal Sarabhai (1963-1971)." ISRO. https://www.isro.gov.in/about-isro/dr-vikram-ambalal-sarabhai-1963-1971.

ISRO. 2020b. "Earth Observation Satellites." ISRO. https://www.isro.gov.in/spacecraft/earthobservation-satellites.

ISRO. 2020c. "International Cooperation.” ISRO. https://www.isro.gov.in/internationalcooperation.

ISRO. 2020d. “SLV.” ISRO. https://www.isro.gov.in/launchers/slv.

Jr., Joseph S. Nye. 1990. "Soft Power." Foreign Policy, no. 80: 153-71. http://www.jstor.org/stable/1148580 .

Malaysian Space Agency (MYSA). 2019. "Background of Malaysian Space Agency (MYSA)." KUALA LUMPUR, MALAYSIA: Malaysian Space Agency (MYSA). http://www.mysa.gov.my/portal/index.php/about-us/background.

Mistry, Dinshaw. 2001. "The Geostrategic Implications of India’s Space Program.” Asian Survey 41 (6): 1023-43. doi:10.1525/as.2001.41.6.1023.

NANYANG TECHNOLOGICAL UNIVERSITY. 2019. "NTU Singapore's Ninth Satellite Successfully Deployed in Space.” Singapore: NANYANG TECHNOLOGICAL UNIVERSITY. https://www.eurekalert.org/pub_releases/2019-01/ntu-ns9012219.php. 
International Journal of Social Science and Economic Research

ISSN: 2455-8834

Volume:06, Issue:03 "March 2021"

Press Information Bureau, and Government of India. 2018. "Project to Support ASEAN Countries." Press Information Bureau Government of India. https://pib.gov.in/newsite/PrintRelease. aspx?relid=178444.

Rao, Radhakrishna. 2014. "India's Space Diplomacy: A Brilliant Masterstroke by Modi." Vivekananda International Foundation. http://www.vifindia.org/article/2014/august/05/india-sspace-diplomacy-a-brilliant-masterstroke-by-modi.

Sarma, Nandini. 2019. "Southeast Asian Space Programmes: Capabilities, Challenges and Collaborations," no. 82.

Seminari, Simon. 2019. "A Euroconsult Analysis: Examining Government Space Budgets." www.satmagazine.com/story.php?number=289878940.

Silver, Andrew. 2019. "The Philippines Creates Its First Space Agency." Nature. Nature. doi:10.1038/d41586-019-02485-9.

Spacewatch. 2018a. "Myanmar Mulling Space Agency; Earth Observation Small Satellite With Japanese Assistance." Spacetechasia. https://spacewatch.global/2018/09/myanmar-mullingspace-agency-earth-observation-small-satellite-with-japanese-assistance/.

Spacewatch. 2018b. "Sultanate Of Brunei To Host Indian Satellite Tracking And Telemetry Station." Spacewatch.

Stares, Paul B. 1987. Space and National Security. Washington, D.C.: Brookings Institution Press.

The Times of India. 2019. "Isro to Launch 5 Military Satellites This Year to Boost' Strategic Assets in Space '." The Times of India. https:/timesofindia.indiatimes.com/india/isro-to-launch5-military-satellites-this-year-to-boost-strategic-assets-in-space/articleshowprint/68713168.cms.

Venkatasubramanian, K V. 2017. "South Asian Satellite to Boost Regional Communication." Press Information Bureau,Government of India. https://pib.gov.in/newsite/printrelease.aspx?relid=161611 1/.

Wikipedia. 2020. “Soft Power.” In , 1-23. Wikipedia. https://en.wikipedia.org/wiki/Soft_power. 